\title{
Pengaruh Berpikir Kreatif dan Percaya Diri terhadap Kemampuan Pemecahan Masalah Matematika
}

\author{
Mualifah $^{1)^{*}}$, Kasih Haryo Basuki ${ }^{2}$, \& Indah Lestari $^{3}$ \\ ${ }^{1}$ SMP Islam Al Kautsar Klapanunggal Bogor, ${ }^{2.3 .}$ Universitas Indraprasta PGRI
}

\section{INFO ARTICLES}

\section{Article History:}

Received: 29-11-2020

Revised: 14-04-2020

Approved: 18-04-2020

Publish Online: 27-06-2020

\section{Key Words:}

Creative Thinking, Self Confidence, Mathematical Problem Solving Ability

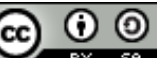
under a Creative Commons AttributionShareAlike 4.0 International License.

\begin{abstract}
The purpose of this research is to find out whether there is an effect of creative thinking and confidence in the ability to solve mathematical problems. This research was conducted at Al Kautsar Klapanunggal Islamic Junior High School in Bogor. This research is a quantitative research with survey method. Data analysis used descriptive analysis techniques to find the average value, mode, median, and standard deviation. Data Requirements Test includes the Normality Test, Linearity Test and Multicollinearity Test. The research hypothesis testing technique used regression analysis and multiple correlation. Sample of this study were 60 students. The results of multiple regression testing obtained values of $F=32.167$ and Sig $=0.000<$ 0.05 which means that the regression coefficient is significant. In other words, there is a significant effect of Creative Thinking and Confidence together on the Mathematical Problem Solving Ability.
\end{abstract}

Abstrak: Tujuan dari penelitian ini adalah untuk mengetahui apakah terdapat pengaruh berpikir kreatif dan percaya diri terhadap kemampuan pemecahan masalah matematika. Penelitian ini dilakukan pada SMP Islam Al Kautsar Klapanunggal Bogor. Penelitian ini termasuk jenis penelitian kuantitatif dengan metode survei. Analisis data menggunakan teknik analisis deskriptif untuk mencari nilai rata-rata, modus, median, dan simpangan baku. Uji Persyaratan Analisis data meliputi Uji Normalitas, Uji Linieritas, dan Uji Multikolinieritas. Teknik pengujian Hipotesis Penelitian yang digunakan adalah analisis regresi dan korelasi ganda. Sampel yang digunakan dalam penelitian ini sebanyak 60 peserta didik. Hasil pengujian regresi ganda diperoleh nilai F $=32,167$ dan $\mathrm{Sig}$ $=0,000<0,05$ yang berarti bahwa koefisien regresi tersebut signifikan. Dengan kata lain, terdapat pengaruh yang signifikan Berpikir Kreatif dan Percaya Diri secara bersama-sama terhadap Kemampuan Pemecahan Masalah Matematika.

Correspondence Address: Jln. Nangka No. 58, Jagakarsa, Jakarta Selatan, 12530, Indonesia; e-mail: basuki.kasihharyo@gmail.com

How to Cite (APA 6 ${ }^{\text {th }}$ Style: Basuki, Mualifah, \& Lestari. (2020). Pengaruh Berikir Kreatif dan Percaya Diri Terhadap Kemampuan Pemecahan Masalah Matematika. JKPM (Jurnal Kajian Pendidikan Matematika), 5 (2): 213-222.

Copyright: : Basuki, K.H., Mualifah., \& Lestari. I. (2020)

Competing Interests Disclosures: The authors declare that they have no significant competing financial, professional or personal interests that might have influenced the performance or presentation of the work described in this manuscript. 


\section{PENDAHULUAN}

Matematika sangat penting peranannya dalam meningkatkan pengetahuan dan keterampilan dasar peserta didik. Oleh karena itu, kemampuan dalam matematika dijadikan sebagai dasar tingkat kemampuan pada pelajaran yang lain. Artinya, jika peserta didik kemampuan dalam pelajaran matematikanya tinggi, maka akan mempengaruhi kemampuan dalam pelajaran yang lain.

Kegunaan matematika menjadi alat penting di berbagai bidang di seluruh dunia mengingat pelajaran matematika merupakan ilmu yang bersifat universal. Menurut Supardi (dalam Leonard, 2015) ada lima alasan perlunya belajar matematika yaitu karena matematika merupakan: (1) Sarana berpikir yang jelas dan logis. (2) Sarana untuk memecahkan masalah kehidupan sehari-hari. (3) Sarana mengenal pola-pola hubungan dan generalisasi pengalaman. (4) Sarana untuk mengembangkan kreativitas (5) Sarana untuk meningkatkan kesadaran terhadap perkembangan budaya.

Peranan matematika begitu sangat penting dalam mengatasi berbagai masalah. Pada dasarnya seseorang tidak terlepas dari masalah, berhasil atau tidaknya seseorang dalam belajar matematika ditandai adanya kemampuan dalam menyelesaikan masalah yang dihadapinya. Kemampuan pemecahan masalah matematika merupakan salah satu kemampuan yang penting dan harus dikuasai oleh peserta didik agar mereka dapat menggunakannya untuk menemukan penyelesaian dari berbagai masalah. Menurut (Gulo, 2002), "Masalah adalah kesenjangan antara situasi nyata dan kondisi yang diinginkan, atau antara kenyataan dengan apa yang diharapkan", jadi masalah merupakan kesenjangan yang menyebabkan situasi yang terjadi berbeda dengan kondisi yang diinginkan. Sehingga membutuhkan alternatif penyelesaian.

Menurut (Siswono, 2008), "Pemecahan masalah adalah suatu proses atau upaya individu untuk merespon atau mengatasi halangan atau metode jawaban ketika suatu jawaban atau metode jawaban yang belum tampak jelas". Jadi suatu masalah yang belum ditemukan metodenya dengan jelas dibutuhkan proses pemecahan masalah agar dapat mengatasi halangan yang dihadapi. Kemampuan peserta didik dalam pemecahan masalah matematika yang berlangsung di sekolah saat ini masih belum optimal. Aktivitas yang sering dilakukan oleh guru biasanya menjelaskan materi, lalu memberikan contoh soal serta pembahasan, kemudian peserta didik diberi latihan soal yang hampir sama dengan contoh soal yang telah dibahas. Akibatnya proses aktivitas ini menyebabkan penghapalan prosedur atau konsep, apabila peserta didik menemui soal yang berkaitan dengan pemecahan masalah, peserta didik masih kesulitan dan kurang kreatif dalam menemukan penyelesaiannya.

Menurut Wardani (2003), "Kemampuan pemecahan masalah matematika adalah proses menerapkan pengetahuan yang telah diperoleh sebelumnya ke dalam situasi baru yang belum dikenal". Ciri dari penugasan berbentuk pemecahan masalah adalah strategi penyelesaiannya tidak langsung tampak. Dalam mata pelajaran matematika, peserta didik dikatakan memiliki kemampuan pemecahan masalah apabila dapat menyelesaikan masalah matematika melalui langkah-langkah pemecahan masalah yaitu memahami masalah, merencanakan cara penyelesaian, melaksanakan rencana, dan menafsirkan hasilnya.

Dalam pemecahan masalah, digunakan proses dasar berpikir untuk memecahkan kesulitan yang telah dikenal atau didefinisikan. Purwadhi (dalam Supardi, 2012) mengatakan bahwa dalam pembuatan keputusan, proses dasar berpikir digunakan untuk memilih cara yang terbaik di antara beberapa pilihan. Banyak faktor yang sebenarnya dapat menunjang peserta didik untuk mampu menyelesaikan masalah matematika. Berpikir kreatif merupakan salah satu faktor yang dapat mendukung kemampuan peserta didik dalam pemecahan masalah. (Purwanto, 2014) menyatakan bahwa "Berpikir adalah suatu keaktifan pribadi manusia yang mengakibatkan penemuan yang terarah kepada suatu tujuan". Sehingga berpikir merupakan suatu kegiatan untuk menemukan pemahaman atau pengertian maupun penyelesaian terhadap sesuatu yang dikehendaki. Sedang menurut (Siswono, 2006) menyimpulkan bahwa proses berpikir kreatif siswa dalam memecahkan dan mengajukan masalah yang mengikuti tahapan berpikir yang terdiri atas tahap menyintesis 
ide-ide, membangun suatu ide, kemudian merencanakan penerapan ide dan menerapkan ide tersebut menunjukkan ciri-ciri yang berbeda untuk tiap tingkatan kemampuan dan menunjukkan perkembangan pola sesuai tingkatnya.

Salah satu kemampuan matematis tingkat tinggi untuk menghadapi permasalahan, baik dalam matematika maupun kehidupan nyata adalah kemampuan berpikir kreatif. (Mahmudi \& Sumarmo, 2015) mendefinisikan berpikir kreatif sebagai proses kontruksi ide yang menekankan pada aspek kelancaran, keluwesan, kebaruan, dan keterincian. Maka hal tersebut menunjukan bahwa kemampuan berpikir seseorang akan dipicu oleh masalah-masalah yang menantang. Berpikir lebih kreatif tidak akan lahir secara tiba-tiba tanpa adanya kemampuan, keingintahuan yang tinggi dan diikuti dengan keterampilan dalam membaca. Seperti yang diungkapkan oleh Porter \& Hermacki dalam (Uno \& Nurdin, 2011) menyatakan bahwa seorang yang kreatif selalu mempunyai rasa ingin tahu, ingin mencoba-coba bertualang serta intuitif.

Berpikir kreatif sangatlah penting dalam belajar matematika. Dengan berpikir kreatif, peserta didik akan mampu menciptakan ide-ide baru yang kreatif dalam belajar. Oleh karena itu berpikir kreatif perlu diarahkan kepada setiap peserta didik sehingga dapat menghasilkan ide baru yang menimbulkan rasa percaya diri dalam mengatualisasikan kemampuannya. Peserta didik yang memiliki rasa percaya diri akan berusaha keras dan memotivasi dirinya agar mampu menyelesaikan masalah dengan hasil yang sesuai diinginkan. Selain itu, peserta didik yang memiliki percaya diri akan memiliki rasa optimis terhadap kemampuan dirinya dalam mencapai suatu tujuan yang diharapkan dan aktif saat proses belajar. Sebaliknya, peserta didik yang minder atau kurang percaya diri cenderung memiliki konsep diri negatif, kurang percaya pada kemampuannya, sehingga dapat menghambat proses belajarnya. Hal itu akan membuat peserta didik tidak berani menunjukkan kemampuan yang dimiliki. Karena sering menutup diri, sehingga kemampuan yang dimilikinya tidak terlihat, padahal kemungkinan sebenarnya kemampuan tersebut dimilikinya.

Rasa percaya diri menurut (Suhendri, 2012) adalah suatu sikap mental atau psikologis positif dari seseorang individu yang memposisikan atau mengkondisikan dirinya dapat mengevaluasi tentang diri sendiri dan lingkungannya. Maka seseorang merasa nyaman untuk melakukan kegiatan dalam upaya mencapai tujuan yang direncanakan”. Peserta didik yang tidak percaya diri akan semakin sulit dalam menyelesaikan masalah matematika. Kesulitan tidak hanya dialami oleh peserta didik yang berkemampuan rendah, peserta didik yang berkemampuan tinggi bisa juga mengalaminya. Pernyataan ini sesuai dengan pendapat Sari Yunita (dalam Zuhriyah, 2013) menyatakan bahwa banyak orang yang gagal bukan karena tidak memiliki pengetahuan atau kemampuan. Mereka merasa gagal karena tidak percaya diri. Ada hubungan antara percaya diri dengan keberhasilan: (1) Peserta didik yang semakin yakin dan percaya akan kemampuan dirinya, maka semakin mantap ia dalam bertindak. (2) Semakin mantap tindakannya, maka akan makin baik pula hasilnya. (3) Hasil yang baik kembali akan menumbuhkan rasa percaya diri yang lebih besar.

Beberapa penelitian yang dilakukan menunjukkan bahwa, terdapat pengaruh percaya diri dan kemandirian belajar terhadap prestasi belajar matematika (Fatimah, 2014). Berpikir kritis berpengaruh signifikan terhadap kemampuan memecahkan masalah matematika (Kusmanto, 2014). Sedang menurut penelitian yang dilakukan oleh (Choridah, 2013) menyatakan "dengan membiasakan pembelajaran berbasis masalah diharapkan siswa percaya diri, gigih, berpikir fleksibel dalam mengeksplorasi ide-ide matematis, dan senang belajar matematika sehingga meningkat disposisi matematisnya". Berdasarkan uraian di atas, peneliti tertarik untuk melakukan penelitian lebih lanjut mengenai pengaruh berpikir kreatif dan percaya diri terhadap kemampuan pemecahan masalah matematika. 


\section{METODE}

Penelitian ini termasuk jenis penelitian kuantitatif dengan metode survei. Penelitian ini mencakup dua variabel bebas yaitu Berpikir Kreatif dan Percaya Diri serta satu variabel terikat yaitu Kemampuan Pemecahan Masalah Matematika. Analisis data menggunakan teknik analisis deskriptif untuk mencari nilai rata-rata, modus, median, dan simpangan baku. Uji Persyaratan Analisis data meliputi Uji Normalitas, Uji Linieritas, dan Uji Multikolinieritas. Teknik pengujian Hipotesis Penelitian yang digunakan adalah korelasi dan regresi ganda.

Tempat penelitian ini dilakukan pada SMP Islam Al Kautsar Klapanunggal Bogor. SMP Islam Al Kautsar yang beralamat di Lebak Pasar Rt. 04 Rw. 02 desa Nambo Kecamatan Klapanunggal Kabupaten Bogor Propinsi Jawa Barat. Populasi pada penelitian ini adalah seluruh peserta didik SMP Islam Al Kautsar Klapanunggal tahun pelajaran 2015/2016 yang berjumlah 165 peserta didik. Sedangkan sampel dalam penelitian ini adalah seluruh peserta didik kelas VII SMP Islam Al Kautsar Klapanunggal yang berjumlah 60 peserta didik. Peneliti dalam hal ini memperoleh data mengenai berpikir kreatif dan percaya diri dengan menggunakan angket (kuesioner) sedangkan kemampuan pemecahan masalah matematika menggunakan soal essay.

\section{HASIL}

Perhitungan data hasil penelitian dilakukan dengan menggunakan bantuan program komputer SPSS. Variabel dengan simbol $\mathrm{X}_{1}=$ Berpikir Kreatif, $\mathrm{X}_{2}=$ Percaya Diri dan $\mathrm{Y}=$ Kemampuan Pemecahan Masalah Matematika, adapun hasilnya sebagai berikut:

Tabel 1. Statistik Deskriptif

\begin{tabular}{|c|c|c|c|c|}
\hline \multicolumn{5}{|c|}{ Statistics } \\
\hline & & $X_{1}$ & $X_{2}$ & $Y$ \\
\hline \multirow[t]{2}{*}{$N$} & Valid & 60 & 60 & 60 \\
\hline & Missing & 0 & 0 & 0 \\
\hline \multicolumn{2}{|c|}{ Mean } & 67.43 & 68.33 & 71.25 \\
\hline \multicolumn{2}{|c|}{ Median } & 67.00 & 68.50 & 70.00 \\
\hline \multicolumn{2}{|c|}{ Mode } & 64 & 65 & 68 \\
\hline \multicolumn{2}{|c|}{ Std. Deviation } & 8.341 & 9.557 & 17.358 \\
\hline \multicolumn{2}{|c|}{ Minimum } & 52 & 48 & 40 \\
\hline \multicolumn{2}{|c|}{ Maximum } & 95 & 96 & 100 \\
\hline
\end{tabular}

Pengujian persyaratan analisis data yang dilakukan dalam penelitian ini adalah pengujian normalitas, linieritas garis regresi parsial antara variabel bebas dan variabel terikat serta uji multikolinieritas. 
Tabel 2. Uji Normalitas One-Sample Kolmogorov-Smirnov Test

One-Sample Kolmogorov-Smirnov Test

\begin{tabular}{llccc}
\hline & & $X_{1}$ & $X_{2}$ & $Y$ \\
\hline$N$ & & 60 & 60 & 60 \\
Normal Parameters $^{a}$ & Mean & 67.43 & 68.33 & 71.25 \\
& Std. Deviation & 8.341 & 9.557 & 17.358 \\
\multirow{2}{*}{ Most Extreme Differences } & Absolute & .110 & .105 & .102 \\
& Positive & .110 & .095 & .077 \\
& Negative & -.070 & -.105 & -.102 \\
Kolmogorov-Smirnov $Z$ & & .850 & .814 & .790 \\
Asymp. Sig. (2-tailed) & & .466 & .522 & .560 \\
\hline
\end{tabular}

a. Test distribution is Normal.

Pengujian Normalitas Data diketahui berdasarkan tabel 2, nilai kolmogorov-Smirnov $Z$ variabel $\mathrm{X}_{1}$ $=0,850$ dan Sig. $=0,466>0,05$, dan nilai kolmogorov-Smirnov $Z$ variabel $X_{2}=0,814$ dan Sig. $=0,522>$ 0,05 serta nilai kolmogorov-Smirnov $Z$ variabel $\mathrm{Y}=0,790$ dan Sig. $=0,560>0,05$, karena semua variabel nilai Sig. > 0,05 maka sampel berasal dari populasi yang terdistribusi normal.

Tabel 3. Hasil Uji Linieritas Berfikir Kreatif $\left(X_{1}\right)$ terhadap kemampuan pemecahan masalah matematika $(\mathbf{Y})$

ANOVA Table

\begin{tabular}{|c|c|c|c|c|c|c|c|}
\hline & & & $\begin{array}{l}\text { Sum of } \\
\text { Squares }\end{array}$ & $d f$ & $\begin{array}{l}\text { Mean } \\
\text { Square }\end{array}$ & $F$ & Sig. \\
\hline \multirow[t]{5}{*}{$Y * X_{1}$} & Between & (Combined) & 9651.333 & 26 & 371.205 & 1.507 & .132 \\
\hline & Groups & Linearity & 1589.743 & 1 & 1589.743 & 6.456 & .016 \\
\hline & & $\begin{array}{l}\text { Deviation } \\
\text { from Linearity }\end{array}$ & 8061.591 & 25 & 322.464 & 1.310 & .232 \\
\hline & \multicolumn{2}{|c|}{ Within Groups } & 8125.917 & 33 & 246.240 & & \\
\hline & \multicolumn{2}{|l|}{ Total } & 17777.250 & 59 & & & \\
\hline
\end{tabular}


Tabel 4. Hasil Uji Linieritas Percaya Diri $\left(\mathbf{X}_{2}\right)$ terhadap kemampuan pemecahan masalah matematika (Y)

\begin{tabular}{|c|c|c|c|c|c|c|c|}
\hline \multicolumn{8}{|c|}{ ANOVA Table } \\
\hline & & & $\begin{array}{c}\text { Sum of } \\
\text { Squares }\end{array}$ & $d f$ & $\begin{array}{c}\text { Mean } \\
\text { Square }\end{array}$ & $F$ & Sig. \\
\hline \multirow[t]{5}{*}{$Y * X_{2}$} & Between & (Combined) & 13165.033 & 26 & 506.347 & 3.623 & .000 \\
\hline & Groups & Linearity & 8272.327 & 1 & 8272.327 & 59.188 & .000 \\
\hline & & $\begin{array}{l}\text { Deviation from } \\
\text { Linearity }\end{array}$ & 4892.706 & 25 & 195.708 & 1.400 & .181 \\
\hline & \multicolumn{2}{|c|}{ Within Groups } & 4612.217 & 33 & 139.764 & & \\
\hline & \multicolumn{2}{|c|}{ Total } & 17777.250 & 59 & & & \\
\hline
\end{tabular}

Pengujian Linieritas Garis Regresi diperoleh hasil bahwa berdasarkan tabel 3, diketahui nilai Deviation from Linearity memiliki nilai $\mathrm{F}=1,310$ dan Sig. 0,232 > 0,05, maka hubungan variabel $\mathrm{X}_{1}$ dengan $\mathrm{Y}$ linear. Sedangkan berdasarkan tabel 4, diketahui nilai Deviation from Linearity memiliki nilai $\mathrm{F}=1,400$ dan Sig. 0,181 > 0,05, maka hubungan variabel $\mathrm{X}_{2}$ dengan $\mathrm{Y}$ linear.

Tabel 5. Hasil Uji Multikolinieritas

\begin{tabular}{|c|c|c|c|}
\hline \multicolumn{4}{|c|}{ Coefficients $^{a}$} \\
\hline & & \multicolumn{2}{|c|}{ Collinearity Statistics } \\
\hline \multicolumn{2}{|l|}{ Model } & Tolerance & VIF \\
\hline \multirow[t]{2}{*}{1} & $X_{1}$ & .996 & 1.004 \\
\hline & $X_{2}$ & .996 & 1.004 \\
\hline
\end{tabular}

a. Dependent Variable: $Y$

Hasil Uji Multikolinieritas berdasarkan tabel 5, diperoleh hasil nilai VIF 1,004 < 10, maka dapat disimpulkan tidak terjadi multikolinieritas, sehingga uji hipotesis menggunakan regresi ganda dapat dilanjutkan.

Tabel 6. Hasil Perhitungan Koefisien Korelasi Pengaruh Variabel $X_{1}$ dan $X_{2}$ terhadap Variabel $Y$ Model Summary

\begin{tabular}{ccccc}
\hline Model & $R$ & $R$ Square & $\begin{array}{c}\text { Adjusted } R \\
\text { Square }\end{array}$ & $\begin{array}{c}\text { Std. Error of } \\
\text { the Estimate }\end{array}$ \\
\hline 1 & $.728^{a}$ & .530 & .514 & 12.104 \\
\hline a. Predictors: (Constant), $X_{2}, X_{1}$ &
\end{tabular}


Tabel 7. Hasil Perhitungan Pengujian Signifikansi Koefisien Regresi Pengaruh Variabel $X_{1}$ dan $X_{2}$ dengan Variabel $\mathbf{Y}$

ANOVA

\begin{tabular}{llccccc}
\hline \multicolumn{2}{l}{ Model } & $\begin{array}{c}\text { Sum of } \\
\text { Squares }\end{array}$ & $d f$ & Mean Square & $F$ & Sig. \\
\hline 1 & Regression & 9425.835 & 2 & 4712.918 & 32.167 & $.000^{a}$ \\
& Residual & 8351.415 & 57 & 146.516 & & \\
& Total & 17777.250 & 59 & & & \\
\hline
\end{tabular}

a. Predictors: (Constant), $X_{2}, X_{1}$

b. Dependent Variable: $Y$

Tabel 8. Hasil Perhitungan Persamaan Garis Regresi Pengaruh Variabel $X_{1}$ dan $X_{2}$ terhadap Variabel Y

Coefficients $^{a}$

\begin{tabular}{|c|c|c|c|c|c|c|c|c|c|}
\hline \multirow{2}{*}{\multicolumn{2}{|c|}{ Model }} & \multicolumn{2}{|c|}{$\begin{array}{c}\text { Unstandardized } \\
\text { Coefficients }\end{array}$} & \multirow{2}{*}{$\begin{array}{c}\text { Standardized } \\
\text { Coefficients } \\
\text { Beta } \\
\end{array}$} & \multirow[b]{2}{*}{$T$} & \multirow[b]{2}{*}{ Sig. } & \multicolumn{3}{|c|}{ Correlations } \\
\hline & & $B$ & $\begin{array}{c}\text { Std. } \\
\text { Error }\end{array}$ & & & & $\begin{array}{l}\text { Zero- } \\
\text { order }\end{array}$ & $\begin{array}{c}\text { Partia } \\
\quad l\end{array}$ & Part \\
\hline 1 & $\begin{array}{l}\text { (Consta } \\
n t)\end{array}$ & $\begin{array}{c}- \\
47.151\end{array}$ & 16.553 & & -2.849 & .006 & & & \\
\hline & $X_{1}$ & .531 & .189 & .255 & 2.806 & .007 & .299 & .348 & .255 \\
\hline & $X_{2}$ & 1.208 & .165 & .665 & 7.313 & .000 & .682 & .696 & .664 \\
\hline
\end{tabular}

a. Dependent

Variable: $Y$

Dari tabel 6, 7 dan 8, akan diuji tiga hipotesis sekaligus yaitu:

1. Pengaruh Berpikir Kreatif $\left(X_{1}\right)$ dan Percaya Diri $\left(X_{2}\right)$ secara bersama-sama terhadap Kemampuan Pemecahan Masalah Matematika (Y)

Dari Tabel 7, terlihat bahwa nilai F $=32,167$ dan Sig $=0,000$. Karena nilai Sig $<0,05$ berarti koefisien regresi tersebut signifikan. Dengan kata lain bahwa terdapat pengaruh yang signifikan variabel bebas Berpikir Kreatif $\left(\mathrm{X}_{1}\right)$ dan Percaya Diri $\left(\mathrm{X}_{2}\right)$ secara bersama-sama terhadap Variabel terikat Kemampuan Pemecahan Masalah Matematika (Y). Dari tabel 6, terlihat bahwa hubungan antara Berpikir Kreatif $\left(\mathrm{X}_{1}\right)$ dan Percaya Diri $\left(\mathrm{X}_{2}\right)$ secara bersama-sama dengan Kemampuan Pemecahan Masalah Matematika (Y) tergolong kuat. Hal ini dibuktikan dengan nilai korelasi (R) sebesar 0,728.

Besarnya kontribusi Berpikir Kreatif $\left(\mathrm{X}_{1}\right)$ dan Percaya Diri $\left(\mathrm{X}_{2}\right)$ secara bersama-sama terhadap Kemampuan Pemecahan Masalah Matematika adalah $53 \%$ yang diperoleh dari nilai $R$ square pada tabel 6, dikali $100 \%$. Dari Tabel 8, diperoleh persamaan garis regresi yang merepresentasikan pengaruh variabel $\mathrm{X}_{1}$ dan $\mathrm{X}_{2}$ terdahap variabel $\mathrm{Y}$, yaitu $\widehat{\mathrm{Y}}=-47,151+0,531 \mathrm{X}_{1}+1,208 \mathrm{X}_{2}$.

2. Pengaruh Berpikir Kreatif $\left(X_{1}\right)$ terhadap Kemampuan Pemecahan Masalah Matematika (Y)

Dari Tabel 8, terlihat bahwa pada $\mathrm{X}_{1}$ nilai $\mathrm{t}=2,806$ dan $\mathrm{Sig}=0,007$. Karena nilai $\mathrm{Sig}<0,05$ berarti terdapat pengaruh yang signifikan variabel bebas $\mathrm{X}_{1}$ (Berpikir Kreatif) terhadap variabel terikat Y (Kemampuan Pemecahan Masalah Matematika). Kontribusi parsial $\mathrm{X}_{1}$ terhadap Y adalah nilai Beta 
kali nilai zero-order (nilai korelasinya) kali $100 \%$ yang terdapat pada tabel 8 , yaitu: $0.225 \times 0.299 \mathrm{x}$ $100 \%=7,62 \%$.

\section{Pengaruh Percaya Diri $\left(\mathrm{X}_{2}\right)$ terhadap Kemampuan Pemecahan Masalah Matematika (Y)}

Dari Tabel 8, terlihat bahwa pada $\mathrm{X}_{2}$ nilai $\mathrm{t}=7,313$, dan Sig $=0,000$. Karena nilai Sig $<0,05$ berarti terdapat pengaruh yang signifikan variabel bebas $\mathrm{X}_{2}$ (Percaya Diri) terhadap variabel terikat $\mathrm{Y}$ (Kemampuan Pemecahan Masalah Matematika ). Kontribusi parsial $\mathrm{X}_{2}$ terhadap Y adalah nilai Beta kali nilai zero-order (nilai korelasinya) kali $100 \%$, yang terdapat pada tabel 8, yaitu: $0.665 \times 0.682 \times$ $100 \%=45,35 \%$

\section{PEMBAHASAN}

Berdasar pada hasil penelitian menunjukkan bahwa terdapat pengaruh yang signifikan variabel bebas Berpikir Kreatif $\left(\mathrm{X}_{1}\right)$ dan Percaya Diri $\left(\mathrm{X}_{2}\right)$ secara bersama-sama terhadap Variabel terikat Kemampuan Pemecahan Masalah Matematika (Y). Hal ini dibuktikan dengan nilai $\mathrm{F}=32,167$ dan Sig. = $0,00>0,05$. Sedangkan kontribusi Berpikir Kreatif dan Percaya Diri secara bersama-sama terhadap Kemampuan Pemecahan Masalah Matematika sebesar $53 \%$, sisanya 47\% karena pengaruh faktor lain yang tidak dikaji dalam penelitian ini.

Hasil Uji lanjut menunjukkan terdapat pengaruh yang signifikan Berpikir Kreatif terhadap Kemampuan Pemecahan Masalah Matematika terlihat dari nilai t = 2,806 dengan Sig = 0,007 < 0,05 sedang besarnya kontribusi berpikir kreatif terhadap kemampuan pemecahan masalah matematika sebesar 7,62\% sisanya 92,38\% karena pengaruh faktor lain yang tidak dikaji dalam penelitian ini dan terdapat pengaruh yang signifikan Percaya Diri terhadap Kemampuan Pemecahan Masalah Matematika terlihat dari nilai $t=7,313$ dengan Sig $=0,000<0,05$ sedang besarnya kontribusi Percaya Diri terhadap kemampuan pemecahan masalah matematika sebesar $45,35 \%$ sisanya $54,65 \%$ karena pengaruh faktor lain yang tidak dikaji dalam penelitian ini.

Berdasar pada hasil penelitian yang bertujuan untuk mengetahui pengaruh berpikir kreatif dan percaya diri terhadap kemampuan pemecahan masalah matematika, maka penelitian ini telah berhasil membuktikan bahwa berpikir kreatif memberikan pengaruh yang positif terhadap kemampuan pemecahan masalah matematika. Hal ini didukung dengan pendapat (Munandar, 2009) yang menyatakan bahwa "Berpikir kreatif atau divergen adalah kemampuan menemukan banyak kemungkinan jawaban terhadap suatu masalah, dimana penekanannya pada kuantitas, ketepatgunaan, dan keberagaman jawaban". Pengertian ini menunjukkan bahwa suatu masalah membutuhkan kemampuan untuk berpikir kreatif. Dengan berpikir kreatif, maka peserta didik mampu memberikan bermacam-macam kemungkinan penyelesaian pada suatu masalah matematika.

Dari penelitian ini teridentifikasi bahwa setiap peserta didik memiliki kemampuan berpikir yang berbeda-beda antara peserta didik satu dengan yang lainnya. Sehingga peserta didik yang kurang kreatif, maka dalam menyelesaikan persoalan matematika tidak dapat memberikan ide atau cara selain yang diajarkan guru dan tidak dapat menyelesaikan soal matematika secara rinci serta peserta didik tersebut merasa tidak percaya diri dengan jawabannya sendiri. Oleh karena itu, percaya diri juga memberikan kontribusi terhadap kemampuan pemecahan masalah matematika.

Rasa percaya diri yang dimiliki setiap peserta didik tentunya berbeda-beda. Peserta didik yang memiliki tingkat percaya diri yang tinggi, akan mampu menunjukkan kemampuan yang dimiliki untuk menyelesaikan masalah matematika dengan penuh rasa percaya diri. Sedangkan peserta didik yang kurang percaya diri akan semakin sulit dalam menyelesaikan masalah matematika karena peserta didik tidak berani 
mencoba untuk menanyakan masalah matematika yang belum difahami. Akan tetapi, jika peserta didik berani mencoba untuk bertanya terkait materi yang belum difahami, maka peserta didik tersebut akan termotivasi dan lebih percaya diri dengan kemampuan yang ia miliki, sehingga mampu menyelesaikan masalah matematika dengan baik. Hal ini sejalan dengan pendapat (Syaifulloh, 2010) yang menyatakan bahwa percaya diri merupakan sikap positif seseorang yang membisakan dan memampukan dirinya untuk meraih apa yang diinginkan. Jadi, semakin tinggi kemampuan berpikir kreatif dan sikap percaya diri, maka semakin meningkat pula kemampuan dalam memecahkan masalah matematika.

\section{SIMPULAN}

Dengan memperhatikan hasil analisis data dan pembahasan hasil penelitian maka dapat disimpulan bahwa (1) Terdapat pengaruh yang signifikan Berpikir Kreatif dan Percaya Diri secara bersama-sama terhadap Kemampuan Pemecahan Masalah Matematika. (2) Terdapat pengaruh yang signifikan Berpikir Kreatif terhadap Kemampuan Pemecahan Masalah Matematika. (3) Terdapat pengaruh yang signifikan Percaya Diri terhadap Kemampuan Pemecahan Masalah Matematika.

\section{DAFTAR RUJUKAN}

Choridah, D. T. (2013). Peran Pembelajaran Berbasis Masalah untuk Meningkatkan Kemampuan Komunikasi dan Berpikir Kreatif serta Disposisi Matematis Siswa Sma. Infinity Journal, 2(2), 194. https://doi.org/10.22460/infinity.v2i2.35

Fatimah, Siti. (2014). Pengaruh Percaya Diri dan Kemandirian Belajar terhadap Prestasi Belajar Matematika. Unpublished Skripsi. Jakarta: Universitas Indraprasta PGRI.

Gulo, W. (2002). Strategi Belajar Peserta Didik. Jakarta: Grasindo.

Kusmanto, H. (2014). PENGARUH BERPIKIR KRITIS TERHADAP KEMAMPUAN SISWA DALAM MEMECAHKAN MASALAH MATEMATIKA (Studi Kasus Di Kelas VII SMP Wahid Hasyim Moga). Eduma: Mathematics Education Learning and Teaching, 3(1). https://doi.org/10.24235/eduma.v3i1.6

Leonard. (2015). Edu Research - Raise The Standard. Jakarta: Universitas Indraprasta PGRI Press.

Mahmudi, A., \& Sumarmo, U. (2015). Pengaruh Strategi Mathematical Habits of Mind $\square$ Mhm $\square$ Berbasis Masalah Terhadap Kreativitas Siswa. Jurnal Cakrawala Pendidikan, 2, 216-229. https://doi.org/10.21831/cp.v0i2.4229

Munandar, Utami. (2009). Perkembangan Kreativitas Anak Berbakat. Jakarta: Rineka Cipta.

Purwanto, Ngalim. M. (2014). Psikologi Pendidikan. Bandung: Remaja Rosdakarya.

Siswono. (2006). Proses Berpikir Kreatif Siswa dalam Memecahkan. tingkat 0, 1-14. 
Siswono, Tatag.Y.E. (2008). Model Pembelajaran Matematika Berbasis dan Pemecahan Masalah untuk Meningkatkan Kemampuan Berpikir Kreatif. Surabaya: Unesa University Press.

Suhendri, Huri. (2012). Pengaruh Kecerdasan Matematis-Logis, Rasa Percaya Diri, dan Percaya Diri terhadap Hasil Belajar Matematika. Prosiding. ISBN: 978-979-16353-8-7.

Supardi, U.S. (2012). Peran Berpikir Kreatif dalam Proses Pembelajaran Matematika. Jurnal Formatif. 2(3): 248-262 ISSN 2088-351X.

Syaifulloh, Ach. (2010). Tips Bisa Percaya Diri. Jogyakarta: Garailmu.

Uno, Hamzah. B. dan Nurdin, Mohamad. (2011). Belajar dengan Pendekatan PAILKEM : Pembelajaran Aktif, Inovatif, Lingkungan, Kreatif, Efektif, Menarik. Jakarta: Bumi Aksara.

Wardani, Laksmi Kusuma. (2003). BERPIKIR KRITIS KREATIF (Sebuah Model Pendidikan di Bidang Desain Interior). Dimensi Interior, $1(2), \quad$ 97-111. http://puslit2.petra.ac.id/ejournal/index.php/int/article/view/16238

Zuhriyah, Tuti (2013). Pengaruh Berpikir Kritis dan Percaya Diri terhadap Hasil Belajar. Unpublished Skripsi. Jakarta: Universitas Indraprasta PGRI. 